\title{
8. Transparency
}

Rasmus Corlin Christensen, Copenhagen Business School

PRE-PRINT VERSION, DECEMBER 2018. ALL COMMENTS WELCOME.

Abstract: In 2013, the G-20 asked the OECD to develop new rules for corporate tax transparency, pushed by civil society activists. World leaders had agreed that increased transparency was urgently needed to help shore up national fiscal systems and alleviate social injustices. These new rules have wide-ranging economic and political consequences for the regulation of global wealth chains (GWCs). Tax transparency is a key factor in the level of information asymmetry between wealth chain 'insiders', such as corporations and tax advisers, and 'outsiders', such as tax authorities and civil society activists. This chapter discusses the 'technicisation' of the OECD policy process to define these new requirements, i.e. the embedding of highly political discussions in a specialised, expertise-intensive policy context. Technicisation constrained the post-crisis political momentum for expanded transparency of corporate wealth chains, but also helped normalize the idea of increased transparency as 'risk assessment' within the policy community. The chapter highlights three key dynamics of technicisation: policyinsulation, re-framing and appropriateness judgments. Evidence is drawn from a qualitative content analysis of documents in the OECD policy debates on corporate tax transparency, and interviews with select informants involved in the policy process. 


\subsection{Introduction}

After the global financial crisis, transparency of corporate tax practices gained substantial momentum as a key global policy ask. Rapid economic integration had created increasing opportunities for corporate capital to take advantage of national tax systems through international regulatory arbitrage. The international corporate tax system rested on century-old principles, originally designed in the 1920s, unable to deal with modern economic reality. World leaders agreed that there was an urgent need to shore up national fiscal systems, address rising debt burdens, and alleviate social injustices, and corporate tax affairs emerged as a central reform target. In 2013, then, the Organisation for Economic Cooperation and Development (OECD) and the G-20 launched the Base Erosion and Profit Shifting (BEPS) project. BEPS introduced 15 concrete action points aimed at comprehensive and coordinated global policy change, with a particular emphasis upon corporate tax transparency, formalised in Action Point 13. This Action Point aimed at making more information available to stakeholders on companies' tax affairs, including a controversial new demand for an unprecedented level of publicity and geographical segmentation, so-called countryby-country reporting (CBCR). Combining strong political backing with the OECD's well-known technical expertise on tax policy, the project was able to produce new globally accepted standards on corporate tax transparency by 2014.

New transparency rules have potentially wide-ranging economic, normative and political consequences for the regulatory context of global wealth chains (GWCs). Tax transparency is a key factor in the level of information asymmetry between wealth chain 'insiders' and 'outsiders', and a key component of corporate financial and reputational management. More transparency means more information available for outsiders to mount regulatory and reputational challenges of corporate tax practices. In particular, the global introduction of CBCR would place significant pressure on corporate wealth chains by mandating unprecedented disclosure by multinational companies (MNCs) of taxes paid in each jurisdiction of operation, alongside a number of real economic activity indicators, allowing for simple quantitative benchmarking by outside stakeholders. Naturally, then, the BEPS Action 13 process brought stakeholders with investments in GWCs to the table, contesting the proposed regulatory changes.

How did the new rules for corporate tax transparency develop, and to whose benefit? As the Introduction to this volume outlines, there is an urgent need to understand how wealth chains are 
regulated, how they are affected by regulatory innovation, and the role of networks of professionals - lawyers, economists and accountants, in both the public and private sectors - in enabling or constraining wealth creation and protection. This chapter addresses these issues by analysing the BEPS Action 13 policy process and the ostensibly technical but fundamentally political battles between professional actors over the right to define new global standards. Literature on professional micropolitics in global governance has highlighted the influence of such competition in technical settings reshaping global politics in accounting (Bötzem 2008, 2012), banking (Lall 2012; Young 2012), finance (Baker 2010; Seabrooke and Tsingou 2014) and tax (Seabrooke and Wigan 2015, 2016; Baden and Wigan 2017). However, there remains a need for further research into the specific "mechanisms of socialization" in global governance, in order to better understand "the processes of 'path generation' through which global policy norms are diffused and translated across jurisdictions" (Broome and Seabrooke 2015, 957). This chapter adds to this literature by exploring the competitive dynamics amongst professionals in the regulatory context of corporate wealth chains, namely corporate tax transparency, and specifically CBCR.

The chapter discusses the 'technicisation' of the BEPS Action 13 policy process, i.e. is the embedding of highly political discussions in a specialised, expertise-intensive policy context. Such settings mask fundamental politics as 'technical' or 'neutral', favouring expertise and technical efficiency, as opposed to public politicised policy settings where explicit political interests dominate. Technicisation constrained the post-crisis political momentum for expanded transparency of corporate wealth chains, but also helped normalize the idea of increased transparency as 'risk assessment' within the policy-making community. The chapter highlights three key dynamics of technicisation: policy insulation, re-framing and appropriateness judgments. These processes of technicisation shaped the views of technical experts and policy-makers on key policy issues and solutions, and eventually policy outcomes. Evidence is drawn from a qualitative content analysis of documents in the OECD policy debates on corporate tax transparency, and interviews with select informants involved in the policy process. Based on this data, the chapter emphasises professional and technical-political dynamics in shaping the changing regulatory context of GWCs.

The chapter is structured as follows: Section two outlines the key battle lines and implications of corporate tax transparency for global wealth chains. I emphasise how expanded transparency reduces information asymmetries, challenges financial and reputational capital and presents opportunities for increased regulatory traction in captive and hierarchy wealth chains. Section three 
introduces the policy context and policy process of BEPS Action 13, detailing the eventual 'transparency compromise'. Section four discusses the technical-political battles over the new corporate tax transparency standards, and details the professional arguments used. I highlight the process of technicisation, how it creates knowledge barriers to mobilisation, how it masks political viewpoints, and its implications for the policy environment, which was characterised by a strong presence of practitioners with private sector tax expertise cautioning against expansive transparency, though normalizing the idea of transparency itself. I argue that technicisation shaped the final policy outcomes by constraining the political momentum for expanded transparency, limiting regulatory traction in GWCs, but also helped the adoption of new policy recommendations by diffusing transparency policy as 'risk assessment' in the policy-making community. In conclusion, I suggest that the chapter highlights the potential of further research on the technicalpolitical processes shaping the changing regulatory context of GWCs.

\subsection{Global wealth chains and corporate tax transparency}

The Global Wealth Chains framework (Seabrooke and Wigan 2017) allows us to systematically link global regulatory innovations with the practices and micropolitics of wealth chain actors. It directs our attention towards the micro-level underpinnings of wealth creation and protection regimes, requiring analyses of the professional and social networks that maintain global wealth chains. Furthermore, by analysing the impact of global regulatory reform on global wealth chains, GWC research can contribute insights on the impact of regulatory innovations on financial accumulation practices. Such investigating allows us to expand knowledge of policy influence and adaptation by wealth chain actors, including the role of professionals in enabling or constraining socio-economic change.

In the case of corporate tax transparency, regulatory innovations touch directly upon captive and bierarchy wealth chains. Captive wealth chains involve major global advisory firms (lead suppliers) providing complex tax advice to corporate tax officers (small suppliers) and MNCs (clients). Here, existing transparency schemes provide authorities with limited regulatory traction ${ }^{1}$. In hierarchy wealth chains, suppliers and clients are more closely integrated, with in-house tax advisers largely

\footnotetext{
${ }^{1}$ Most developed countries, and increasingly developing countries as well, have legislated and expanded tax transparency documentation requirements over the past two decades.
} 
performing the tax structuring. This integration allows regulators less transparency about tax practice, and thus more clouded oversight. Within these two types of chains, corporate tax planning are central to wealth strategies, and transparency crucial to potential regulatory intervention. Aggressive tax behaviour has allowed some companies to shift profits artificially to low-tax jurisdictions, minimising tax burdens significantly (Dharmapala 2014). In response, increased transparency has been identified as a central lever for combating these strategies, enabling regulators to identify and act on key risk areas (OECD 2013).

Expanded corporate tax transparency, if adopted across the world, would enable unprecedented challenges to corporate financial and reputational capital by reducing the information asymmetries in corporate wealth chains. Transparency is a key assets in the governance of global wealth chains, providing benefits for wealth chain insiders and costs for wealth chain outsiders. For clients and suppliers, lack of transparency can contribute to holding outsiders at bay, protecting wealth accumulation strategies and reputational capital. If authorities, activists and/or the public are unable to decipher financial structures and tax-related transactions, they are unlikely to mount effective regulatory and reputational interventions. For regulators, lack of transparency obscures oversight. Importantly, 'regulators' here is understood broadly, including the media and civil society activists alongside government authorities. While the latter perform a legislative regulatory function, the latter perform a normative regulatory function. Transparency provides regulators with more power, easing normative, administrative and legislative intervention and critique by strengthening regulatory capacity. In turn, more information would impose financial and reputational costs upon MNCs (whether or not any legal misconduct had taken place). For instance, previous advances in corporate tax transparency has allowed civil society activists to advance impactful criticisms of banks' tax practices as expressions of misalignment of taxable profits towards low-tax jurisdictions (Dyreng, Hoopes, and Wilde 2014; Murphy 2014; CCFD-Terre Solidaire et al. 2016; Oxfam 2017). Thus, if expansive country-by-country reporting were to be required of companies through BEPS 13 , it would bring regulators closer to clients and suppliers, increasing the likelihood of regulatory and normative liability for captive and hierarchy wealth chains. Figure 1 illustrates this, contrasting the pre-BEPS situation (position 0) and potential effects of BEPS 13 (position 1) on tax transparency. 
Figure 1. Potential effects on wealth chain information asymmetries of transparency

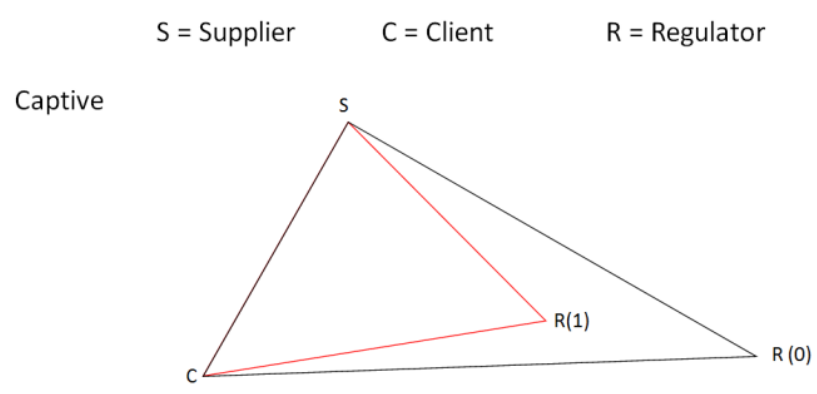

Hierarchy

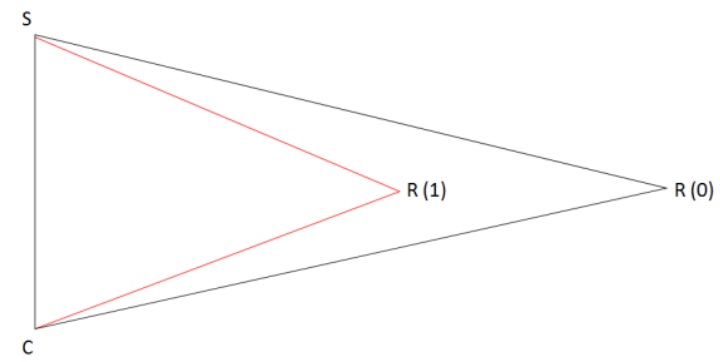

If information asymmetries were reduced through transparency, beneficiaries of captive and hierarchy chains might well need to re-think wealth strategies. Extra costs would be imposed on fiscal arbitrage in the form of administration compliance burdens and reputational risk, etc. In response, suppliers of wealth chain products, such as tax advisers, might need to mobilise increasingly high-level capabilities to help clients restructure tax affairs to conform to a new regulatory environment. This could either take the form of reorganisation to avoid reputational exposure through 'creative compliance' or reorganisation to meet new norms and minimise reputational challenges altogether. In the former scenario, MNCs might restructure to maintain tax advantages whilst formally meeting regulatory demands, bolstering information asymmetries and existing wealth chain strategies. For instance, captive wealth chain suppliers are increasingly marketing 'tax effective supply chain management' services, enabling clients to establish integrated operational structures that are 'tax sustainable' in the face of regulatory action (chapter 5 in this volume). In the latter scenario, MNCs might de-risk and simplify financial structures, moving towards more market-based wealth chain structures of lower complexity and lower regulatory liability. In this vein, previous increases in transparency of corporate tax affairs has led businesses to rethink tax practices due to potential reputational pressures, with tax reputation management becoming a key issue for high-level corporate executives (EY 2016; PwC 2016). A 2016 industry survey of American CEOs summarises the point: 
"Many companies are restructuring their global operations and looking at their supply chains, with a view to minimizing any potential brand or reputational risk. (...) They don't want to deal with the potential fallout of negative publicity should a tax arrangement a ttract attention from media or shareholders." (KPMG 2016, 26)

\subsection{BEPS Action 13: A transparency compromise}

In the wake of the financial crisis, the BEPS project eventually emerged as the key initiative to enhance corporate tax transparency. Corporate tax transparency was not initially on the post-crisis agenda for global leaders, as they had initially focused on tax havens (Rixen 2013; Lesage and Kacar 2013). However, as international tax reform moved into the global spotlight, OECD bureaucrats and activists mobilised, leveraging years of work 'in the shadows' on proposals to strengthen the international tax system. They lobbied G8 and G20 officials successfully, bringing key policy asks - including transparency - on the agenda (Baker 2013; Eccleston and Woodward 2014, 223). Thus, formally prompted by the G20 leaders at the June 2012 Summit in Los Cabos, Mexico (G20 2012), the work began at the OECD. The OECD issued a scoping report in February 2013, followed by a policy project launch and a specific Action Plan in July. The envisioned regulatory changes were far-reaching, targeting a broad range of issues, from abuse of bilateral tax treaties, international tax mismatches, corporate debt gaming, multilateral tax cooperation and, importantly, corporate tax transparency (OECD 2013).

Action 13 on transfer pricing documentation and country-by-country reporting (CBCR) was the most controversial project item. CBCR had been a hotly contested issue for years, with civil society activists seeking to mandate extensive public disclosure by MNCs. For them, it was about "putting MNC activity 'on the record”' (Murphy 2012). However, CBCR had faced substantial opposition from policy-makers, businesses and tax professionals due to its perceived threat to entrenched legal principles, to corporate privacy, and to competitiveness (Lesage and Kacar 2013; Baden and Wigan 2017). Activists had found some momentum with the adoption of Dodd-Frank in the US and the Accounting and Transparency Directives in the EU, both of which required publication of 'lite' versions of CBCR in targeted industries. Emboldened, civil society activists worked to push CBCR onto the BEPS agenda after it had been entirely absent from the initial OECD scoping report. Successful, the G8 leaders in June 2013 formally called on the OECD to develop a global standard for CBCR (G8 2013). The July 2013 Action Plan thus included Action 13 to 're-examine transfer 
pricing documentation', with the aim to "enhance transparency for tax administration, taking into consideration the compliance costs for business" (OECD 2013).

Formally, then, the political direction had been set by global leaders in the G8 and the G20, and key points of decision-making continued to formally rest with ministers and high-level diplomats. Within that context, the practical policy formulation process now lay largely at the technical level, specifically with OECD bureaucrats and the broader interest ecology of tax experts in public administrations, business, academia, and (to a lesser extent) civil society. The Action 13 work was managed by Working Party 6 (WP6) of the OECD's Committee of Fiscal Affairs (CFA). WP6 and the CFA both consist of national delegates, who met every 3-4 months in addition to informal bilateral talks. WP6 and the CFA had support from a dedicated BEPS secretariat in the OECD's tax directorate, responsible for preparing most documentation and advancing discussions, drafting policy recommendations, and engaging proactively with stakeholders throughout the process. From July 2013 to May 2014, WP6 and the OECD secretariat planned six official consultations on CBCR, receiving a range of inputs from stakeholders. They held four 'regional' consultations (in Korea, Colombia, South Africa, and Paris) and two events for the wider public in Paris. Then, in June 2014, the WP6 presented the policy recommendations following the technical discussions to the CFA, which were approved and later ratified by the G20 Finance Ministers in September.

The outcome of the BEPS Action 13 policy process can be labelled a 'transparency compromise'. Issued in September 2014, the final Action 13 report contained recommendations for countries to adopt national documentation requirements on corporate tax transparency, asking for more information than ever before, including the controversial addition of CBCR (OECD 2014c). However, the recommendations had also re-formulated the purpose of CBCR from prior political discussions. Far removed from "putting MNCs on the record", the stated purpose of CBCR now was to enhance risk assessment by tax administrations, subject to considerations of business compliance costs. The CBCR template itself included seven data points for economic comparison, down from fifteen in the initial draft. This was also significantly less than had initially been advocated by CBCR activists (Murphy 2003), notably excluding key benchmarks on cross-border payments and labour costs. Furthermore, the report stipulated that CBCRs should be disclosed to tax administrations in the MNC groups' parent headquarter country (i.e. largely the global North), to be obtained by other countries through bilateral tax agreements. This proved another departure from prior political discourse, which had emphasised broad-based access for the non-North (who 
generally have few tax agreements in place for such exchanges). Finally, the disclosure requirements were limited to companies with more than $€ 750 \mathrm{~m}$ in annual revenue, representing around $10 \%$ of global MNCs, again a narrowing compared to the original activist intentions and previous regulation in the EU and the US.

In wealth chain terms, the final recommendations offer potential to reduce wealth chain asymmetries by providing authorities with more information - but less so than the post-crisis political momentum had opened up space for. With more than 100 countries committing to implementing the Action 13 recommendations, the transparency compromise is certain to have global effect. While the CBCR recommendations have been successfully diffused, its scope and nature has become critically limited compared to the intentions of those who pushed it onto the global agenda. Consequently, the potential for new regulatory traction on global wealth chains remains constrained. Figure 2 illustrates this, contrasting the pre-BEPS situation (position 0), the original activist intentions (position 1), and the actual recommendations (position 2) in terms of effect on wealth chain information asymmetries.

Figure 2. Actual effects on wealth chain information asymmetries of transparency

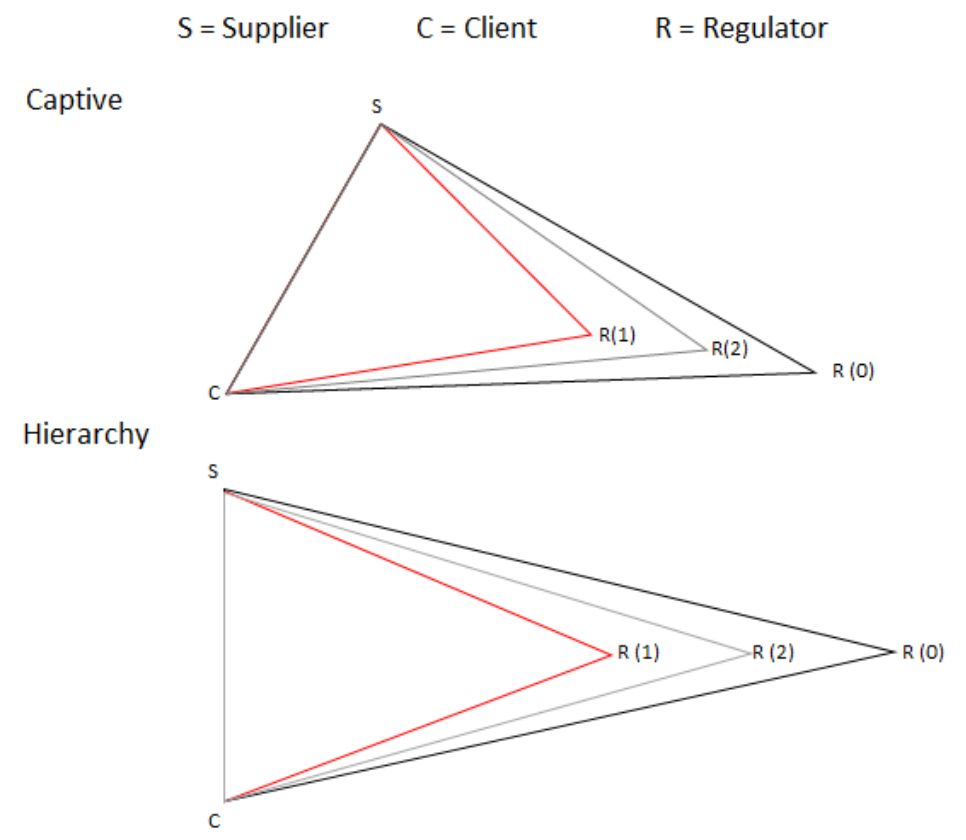




\subsection{Technical-political battles}

How did this transparency compromise come about? With the main stakes and the policy process outlined, I now turn to the technical-political battles around new global standards for tax transparency. Specifically, I discusses the 'technicisation' of the OECD policy process. This technicisation shaped the new transparency requirements for corporate wealth chains through three key dynamics: policy insulation, re-framing and appropriateness judgments. I consider each of these in turn. These processes shaped the view of technical experts and policy-makers on key policy issues and solutions, and eventually policy outcomes. The argument is supported here by a qualitative content analysis (Schreier 2012) of the two public consultations in BEPS 13, as well as interviews with select informants involved in the policy process. For the QCA, 183 comment letters were mapped, detailing the respondent, its (organisational) type and policy positions on seven key issues of debate ${ }^{2}$. For each comment letter, the average policy position was aggregated from its position on the seven key issues, on a scale of one to three. One marks a general preference for expansive wealth chain transparency and three demark a general preference for limited wealth chain transparency. The policy positions provide an overview of the structure of the debate but they also reflect the main wealth chain politics: more transparency means less information asymmetry and thus more scope for reputational challenges and regulatory traction, and vice-versa.

The first key dynamic of technicisation was policy insulation. Policy insulation prevents outside influence on established institutions by infusing them with structural ideational inertia, making such settings more likely to resist change (Drezner 2000; Figueiredo 2002; Broome and Seabrooke 2015). This is a well-established dynamic in the case of the OECD's international tax policy-making, where insulation from popular politics had "facilitated normative settlement and the emergence of a transnational "epistemic community” embodying it" (Genschel and Rixen 2015, 36). At its core, the technical OECD policy setting insulated professionals involved in policy-making from politicisation and public conflict. In the political sphere, the conditions for uptake of CBCR had been favourable. Extensive media coverage, crisis momentum, and rising popular salience of issues

\footnotetext{
2 These issues were: The filing and sharing mechanism, materiality thresholds, and five specific data points (crossborder payments, nature of subsidiaries' business activity, number of employees, tangible assets, and total employee expense)
} 
related to corporate tax avoidance and inequality had provided an ideal platform for critical actors push tax transparency.

The technical policy space was entirely different. As opposed to politicians, media and the wider public, the technical environment featured primarily expert stakeholders, such as national delegates, OECD bureaucrats and the widercommunity of tax professionals. Such professionals can be more closely connected amongst each other within the technical community, sharing policy ideas and epistemic frames, than they are through affiliations with a particular organisation or nation (cf. Seabrooke and Sending 2014). As one interviewee noted, "the group of people involved in the process is relatively small; we see each other regularly" (interview with tax advisor \#1), while another said, "they all know each other very well, by first name; they are extremely chummy" (interview with OECD official \#1). By embedding key policy discussions in such an "epistemic community" (Haas 1992), policy-making professionals were effectively insulated from messy popular politics, enabling a strong technical and political unity.

An overwhelming majority of private sector tax specialists in the policy discussions, cautioning against expansive transparency, furthered policy insulation. There was dominant mobilisation of private sector tax expertise to the public policy consultation as well as to informal discussions. And the majority were strongly against expansive new transparency demands. Figure 3 below plots the average policy position of all comment letter sent to the OECD, broken down by respondent type,

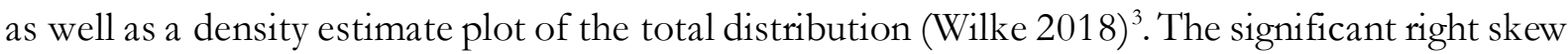
- except for civil society - indicates a broad consensus amongst contributors preferring a limited expansion of transparency. Across the comment letters, the average policy position scored 2.4 (median 2.5). This aligns with the composition of respondents, largely dominated by tax advisors, corporations and business lobbies, i.e. groups with high degree of technical expertise on tax matters as well as investment in existing global wealth chains. In opposition, marginal voices from civil society, including researchers and developing country actors, remained in a small minority. As one interviewee said of these groups' influence in the policy deliberations, "we can have a voice but not a vote" (interview with civil society activist \#1).

\footnotetext{
${ }^{3}$ Comment letters that did not express any particular policy opinions on the key issues were excluded, 21 in total.
} 
Figure 3. Distribution of policy positions on tax transparency

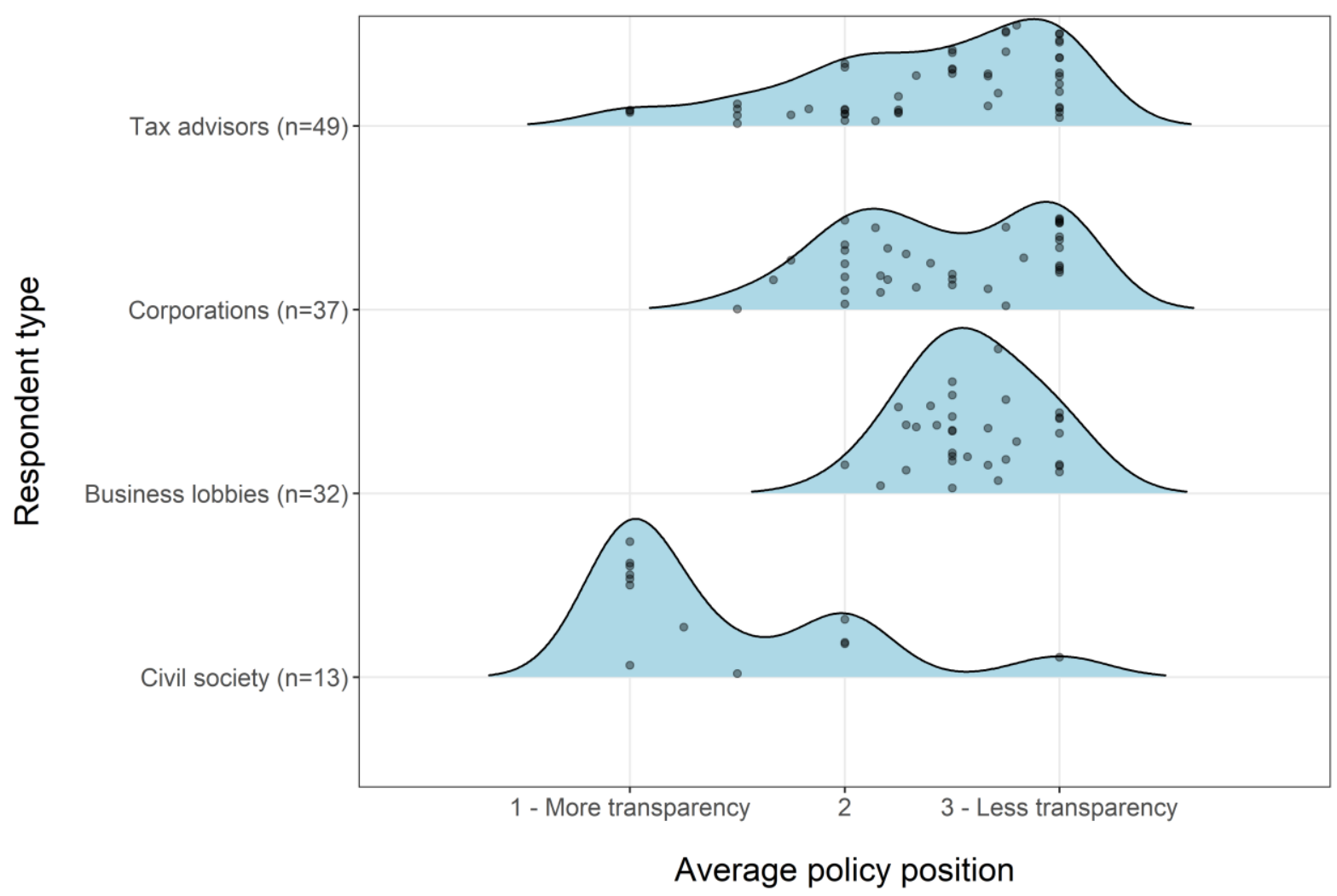

A central feature of structure of mobilisation was knowledge barriers. Technicisation creates obstacles to political inclusion and engagement, requiring detailed practical expertise and thus limiting the range of actors able to credibly contest policy debates. Policy discussions were conducted in a highly technical, specialised language, thick with specific legal and economic terminology. While many tax practitioners found this natural, activists and other non-specialists were absent by choice or necessity. This excluded a number of voices critical of global wealth chains, and favouring more transparency, from the deliberations, thus contributing to relative consensus amongst participants against expansive transparency.

It should be noted that a small minority of activists took on these challenge, banding together relevant expertise to participate meaningfully in technical discussions. In particular, the BEPS Monitoring Group, a coalition of civil society tax experts, sought to aggregate activist knowledge on tax matters in order to mobilise counter-expertise (cf. Quack 2016). The Group's engagement with technical discussions was led by Richard Murphy, an accountant-turned-activist and creator of the activist-backed CBCR standard (Murphy 2003); Sol Picciotto, emeritus professor of law; and Jeffery Kadet, a tax accountant and former tax partner at Arthur Andersen. Alongside attempts to 
make explicit the broader political implications of the corporate tax transparency discussions, the Group arguing their case using specific technical comments. Their comment letter, for instance, leveraged economic expertise in arguing that CBCR should be made public, as it "would make the system more effective by promoting consistency" (OECD 2014b). It also argued in extensive detail for a "top-down" approach to CBCR, noting that such an approach would minimise double taxation by aligning with recognised accounting standards (OECD 2014b). Such structured organisation of counter-expertise and detailed expertise-based arguments was largely unprecedented from activists in technical tax processes.

The second key dynamic of technicisation was re-framing. Framing is the process by which events or ideas are made sense of, which in turn "organize experiences and guide action" (Snow et al. 1986). The way corporate tax transparency and CBCR was made sense of and talked about shaped reactions to the proposals. In particular, the technicised policy process re-framed CBCR, reengineered conventional understandings of the purpose of $\mathrm{CBCR}$ by institutionalising and diffusing an alternative framing of corporate tax transparency measures. Already in the June G8 declaration, and shortly thereafter in the July OECD Action Plan, the signs of expert re-framing had been evident. Whereas activists had advanced public CBCR as a financial reporting standard to expose corporate tax avoidance, the adoption onto the global agenda framed CBCR as "for tax authorities". Suddenly, CBCR had shifted from a public concern and an accounting issue to a private administrative matter under the rubric of "transfer pricing documentation", over which OECD had exclusive authority as the global standard-setter. Furthermore, the idea of CBCR as a lever for systemic change was abandoned. Activists had promoted CBCR as a tool for fundamentally reshaping the international corporate tax system, which they saw as easily manipulated and unjustly favourable to MNCs (Murphy 2013; Tax Justice Network 2013). They hoped that creating transparency of MNCs' (mis-)allocation of profit in relation to economic activity (sales, labour, assets) would help usher in a new era. However, the G8 declaration and the OECD Plan defined CBCR as exclusively a risk assessment tool for governments, in line with existing OECD framing of transfer pricing documentation, thus striking a significant blow to activist framings and aspirations.

This re-framing of CBCR was furthered in the technical policy discussions, with significant political implications. While it may not be surprising that expert professionals, under political pressure to adopt CBCR into policy discussions on their 'home turf', framed CBCR in (for them) conventional 
terms, such as transfer pricing risk assessment, this co-optation is by no means a 'neutral' process. What is technical is political. Technicisation and re-framing steered discussion towards a limited range of topics, effectively disadvantaging certain political viewpoints and avenues. As one interviewee noted, "By breaking it down into technical, detailed topics, people focus on those minor technical rather than the larger issues" (interview with tax advisor \#2). The June 2014 letter from the BEPS Monitoring Group to the OECD CFA lamented, "the BEPS policy scope should be wider. The Action Plan does not suggest any re-examination of the basic principles of the system” (BEPS Monitoring Group 2014). The discussion of CBCR as a technical issue of risk assessment for tax administrations, and part of the standard transfer pricing documentation package, rather than a revolutionary tool (as in the activist framing), precluded debate on the fundamentals of international corporate taxation. Instead, the experts discussed such issues as the costs of language translations. Still, even such "minor technical issues" have significant political and distributional implications. For instance, the exclusion of data points on national economic activity from the CBCR, such as local labour costs, was largely justified in terms of its (lack of) necessity for risk assessment. However, as labour costs are amongst the most popular benchmarks for cross-border comparison of corporate profit (mis)alignment, its exclusion was a blow to 'outsiders' looking to mount reputational and financial challenges to MNC tax strategies.

Re-framing also contributed in some ways to further support for (a specific idea of) CBCR, rather than exclusively opposition. Because CBCR was accepted into the 'home turf framing of the technical tax community as a risk assessment tool under the rubric of transfer pricing documentation, debate focused on the scope and content of the CBCR requirements more than its introduction altogether. For instance, the comments requested by the OECD specifically centred on 'practical details', such as whether the CBCR should be compiled "bottom-up" (from local statutory accounts) or “top-down” (from MNC groups' consolidated income statements), or regarding the most appropriate approach to translation requirements (OECD 2014a). Very few comment letters argued that CBCR should be abandoned altogether; rather, the technical community recognized the idea for the purposes of risk assessment, focusing on tailoring the CBCR to suit such requirements. Largely, this meant limiting its scope and content but not reject the very idea of country-by-country reporting. One particularly critical comment letter, from the International Alliance for Principled Taxation (IAPT), noted: 
"[T] he extraordinarily detailed template demands far more information than is needed for the high level risk assessment tool the OECD was mandated to develop. The IAPT therefore recommends limiting the $\mathrm{CbC}$ template data elements to those identified by the G8 and G20 as needed to provide a high level risk assessment tool.” (OECD 2014b)

The third key dynamic of technicisation was appropriateness judgments. In a policy discussion, different actors put forth different arguments to establish control over the discussions, with each argument evaluated according to its "appropriateness", which is defined socially in the organisational setting at hand (Lazega 1992). In the case of BEPS Action 13, the overwhelming majority of participants in the technical-political, insulated from diverse and conflicting political views, consistent applied a narrow technical framing. In such settings, where technical-expert information flows proliferate, abstract and codified knowledge tends to dominate (Boisot 1994). The 'benchmark' for arguments in BEPS Action 13 was based predominantly on specific legal and economic expertise, often drawn from private sector experience, and this favoured certain policy arguments over others, fostering a consensus around what constituted feasible policy solutions.

Specifically, practitioners' expertise-based arguments against expansive transparency clashed most notably with moral arguments of activists and emerging countries. Tax professionals emphasised legal uncertainties and economic inefficiencies in technical discussions. Concerned with the tradeoffs of expansive new transparency requirements, opponents of wide-ranging CBCR framed new demands as risks towards double taxation and competitiveness. On the former, practitioners argued that such tax transparency would challenge tax administrations' processes, inclining them towards irrelevant a nalyses, thus obscuring overall tax compliance, creating double taxation and unnecessary administrative burdens. The comment letter from A3F, a French tax practitioner collective, wamed of "a significant risk that the DD [discussion draft] opens the door to formula-based allocation of income or systematic application of profit-split upon audit by some countries, ignoring the taxpayer's business and value creation model, functional analysis and related transfer pricing methodology" (OECD 2014b). On the latter, commenters opined that corporate competitiveness would suffer from added transparency demands, exposing commercial secrets, putting companies at a competitive disadvantage. The comment letter from BIAC, an institutionalised business advisory group to the OECD, found that the proposed documentation "largely relates to highly confidential or commercially sensitive information, and, if inadvertently shared beyond the intended recipient, could present a significant risk to the group in question (OECD 2014b). 
In opposition, activists and others largely argued for expanded disclosure based on moral persuasion. The few activists attending the technical debates often opted for normative claims, transported in to the technical setting from a politicised starting point. Civil society professionals from Eurodad, Christian Aid, Oxfam and the Jubilee USA Network largely refrained from technical comments in the BEPS 13 consultation, instead problematising the policy forum (OECD) itself and the lack of developing country involvement. For instance, the Eurodad comment letter noted, "[W] also find it problematic that the decision by OECD to suggest a confidential country-bycountry reporting system seems to have been taken before the regional BEPS consultations of developing countries have even started" (OECD 2014b). This was in tune with the arguments by ActionAid, an activist organisation that did not participate in the technical discussions, whose public call to the UK government was headlined, "The BEPS process: failing to deliver for developing countries" (ActionAid 2014). Similarly, there was hardly any difference between the framing in Oxfam's consultation letter to the OECD (OECD 2014b) and their public BEPS briefing paper (Oxfam 2014), both of which stressed the structural inequality faced by developing countries in international tax cooperation.

Moral appeals were in an overwhelming majority and did not align with the dominant 'appropriateness' in the technical-political setting. However, arguments based on tax-specific expertise were far more likely to be perceived as acceptable. In contrast to civil society's 'justice' claims, the technical policy-making community took account of tax expertise-based arguments, providing authority to claims about corporate competitiveness, confidentiality and compliance costs. Such technical comments held primacy in the OECD BEPS process (Elschner, Hardeck, and Max 2017; Büttner and Thiemann 2017; see also BEPS Monitoring Group 2014). As one informant, that civil society were "pretty much excluded from everything", while business tax practitioners had a "strong relationship and involvement with OECD staff (interview with OECD official \#2). This notion was reflected on the practitioner side. One interviewee found that practitioners had been "successful in convincing the OECD that you don't need all that information [in the CBCR]" (interview with tax professional \#2), and another noted that discussions amongst professionals had "reduced the number of CBCR data points" (interview with tax professional \#3). 
This has historically been a feature of OECD policy-making, including in tax policy, where engagement with tax experts from the business sector has been firmly established and successfully institutionalised, in sharp contrast to engagement with civil society (Ougaard 2011; Picciotto 2015). Simply put, in an environment of tax practitioners and specialists with a technical frame of reference, discussants with only general knowledge of tax issues were unlikely to find support for claims based on non-specific expertise. In such established professional territory, such as international tax policy, it can be particularly difficult to introduce radical new policy ideas because of the high levels of professional consensus on policy issues and solutions (Genschel and Rixen 2015; Büttner and Thiemann 2017). For activists, who had been successful in pushing tax transparency onto the global agenda through broad-based campaigning and targeted lobbying, as well as developing countries and other marginalised actors, the technicised process of BEPS 13 provided a frustrating experience.

These dynamics of technicisation effectively shaped the policy process and the policy outcomes. Technicisation contributed to taming the surge for expanded transparency that had been established in a broader political sphere, thus limiting new reputational pressures on corporate wealth chains. The BEPS Action 13 were characterised by a specialised, expertise-intensive policy context. Technical knowledge barriers and professional dynamics enabled an overwhelming consensus amongst the policy-engaged community of professionals that cautioned against expansive new transparency requirements. In particular, this consensus featured arguments based on economic and legal expertise against 'unnecessarily burdensome' CBCR, which was consistently framed as a tool for tax authorities only, as a threat to corporate commercial sensitivity and competitiveness, and a danger for double taxation and legal uncertainty. This provided an effective counter, within the technical setting, to wider calls for transparency from popular politics. However, CBCR was not rejected outright. Technicisation helped normalize the idea of increased transparency, initially pushed onto the global agenda by critical activists, as 'risk assessment' within the community of policy-makers. The debates focused on the appropriate scope and use of transparency, rather than whether or not corporate tax transparency and CBCR was acceptable as such. The result was a policy outcome that restrained the potential for reputational challenges to captive and hierarchy wealth chains, but helped diffuse and entrench a (limited) expansion of transparency globally. 


\subsection{Conclusion}

This chapter has discussed the technicisation of policy discussions around corporate tax transparency. Technicisation helped subdue political momentum for new transparency demands, blunting the potential for new financial and reputational challenges to corporate wealth chains. At the same time, it helped normalize the idea of transparency as 'risk assessment'. This happened through policy insulation, re-framing and appropriateness judgments. Policy insulation fostered technical unity, established knowledge barriers to participation, and contributed to the diffusion of policy consensus against expansive transparency (but accepting transparency itself), amongst technical experts and policy-makers. Re-framing moved CBCR from a revolutionary public lever for systemic change to a confidential risk assessment tool, thus institutionalising a new understanding of CBCR, subject primarily to concerns of economic efficiency and legal uncertainty, rather than notions of 'fairness' and 'justice'. The dynamics of appropriateness judgments promoted a favouring of tax-specific expertise-based arguments over moral claims. By embedding discussions where participants' expertise and frame of reference was predominantly defined by corporate competitiveness, confidentiality and compliance costs, those concerns came to determine the feasibility of policy proposals. The result was a 'transparency compromise', a limited expansion of transparency, less than intended by those who originally pushed CBCR on to the global policy agenda, but still more than in the pre-BEPS context.

The case of BEPS Action 13 suggests a need to pay attention to technicisation in the making of international tax rules and the changing regulatory context of wealth chains. Professional interactions and technicisation are a central yet often-overlooked feature of highly technical, complex policy processes, shaping the definition of new rules for global wealth chains. These rules have profoundly political consequences, affecting information asymmetries, regulatory liability and the overall relationship and governance among actors within global wealth chains. The case here demonstrates the importance of understanding professional dynamics in reworking such information asymmetries and regulatory traction for captive and hierarchy wealth chains, where transparency of tax and transfer pricing strategies are central. However, as the case is limited to one particular policy process around corporate tax transparency under the auspices of the OECD, there is significant scope for further research on the mobilisation and interplay of expertise-based actors in policy processes shaping wealth chain regulation at the national, regional and international levels. 


\section{References}

ActionAid. 2014. 'The BEPS Process: Failing to Deliver for Developing Countries'.

Baden, Adam, and Duncan Wigan. 2017. 'Professional Activists on Tax Transparency'. In Professional Networks in Transnational Governance, edited by Leonard Seabrooke and Lasse Folke Henriksen, 130-46. Cambridge: Cambridge University Press.

Baker, Andrew. 2010. 'Restraining Regulatory Capture? Anglo- America, Crisis Politics and Trajectories of Change in Global Financial Governance'. International Affairs 86 (3): 647-63. . 2013. 'The Lough Erne Summit and the Tax Justice Story'. The Political Studies Association (PSA) - Political Insight, June. https://www.psa.ac.uk/political-insight/blog/lough-ernesummit-and-tax-justice-story.

BEPS Monitoring Group. 2014. 'Civil Society Perspectives on the G20/OECD BEPS Process to Date'. https://bepsmonitoringgroup.files.wordpress.com/2014/06/cs-letter-to-cfa-june2-2014.pdf.

Boisot, Max. 1994. Information and Organizations: The Manager as Anthropologist. London: HarperCollins.

Bötzem, Sebastian. 2008. 'Transnational Expert-Driven Standardisation-Accountancy Governance from a Professional Point of View'. In Transnational Private Governance and Its Limits. London: Routledge, 44-57. https:/ / ecpr.eu/Filestore/PaperProposal/7e18fd9f-c6d44ea3-aceb-fda585ba234f.pdf.

- 2012. The Politics of Accounting Regulation: Organizing Transnational Standard Setting in Finanaial Reporting. Cheltenham, UK: Edward Elgar Pub.

Broome, André, and Leonard Seabrooke. 2015. 'Shaping Policy Curves: Cognitive Authority in Transnational Capacity Building'. Public Administration 93 (4): 956-72. https://doi.org/10.1111/padm.12179.

Büttner, Tim, and Matthias Thiemann. 2017. 'Breaking Regime Stability? The Politicization of Expertise in the OECD/G20 Process on BEPS and the Potential Transformation of International Taxation'. Accounting, Economics, and Law: A Convivium 0 (0). https://doi.org/10.1515/ael-2016-0069.

CCFD-Terre Solidaire, Oxfam France, Secours Catholique, and la Plateforme Paradis Fiscaux et Judiciaires. 2016. 'En Quête De Transparence: Sur La Piste Des Banques Francais Dans Les Paradis Fiscaux'. 
Dharmapala, Dhammika. 2014. 'What Do We Know about Base Erosion and Profit Shifting? A Review of the Empirical Literature'. http://papers.ssrn.com/sol3/papers.cfm?abstract_id=2398285.

Drezner, Daniel W. 2000. 'Ideas, Bureaucratic Politics, and the Crafting of Foreign Policy'. American Journal of Political Science 44 (4): 733. https:/ / doi.org/10.2307/2669278.

Dyreng, Scott D., Jeffrey L. Hoopes, and Jaron H. Wilde. 2014. 'Public Pressure and Corporate Tax Behaviour'. Fisher College of Business Working Paper Series 2014-02-003. Ohio State University. http://www.sbs.ox.ac.uk/sites/default/files/Business_Taxation/Docs/Publications/Wo rking_Papers/series-14/WP1416.pdf.

Eccleston, Richard, and Richard Woodward. 2014. 'Pathologies in International Policy Transfer: The Case of the OECD Tax Transparency Initiative'. Journal of Comparative Policy Analysis: Research and Practice 16 (3): 216-29. https://doi.org/10.1080/13876988.2013.854446.

Elschner, Christina, Inga Hardeck, and Marcel Max. 2017. 'Lobbying on the BEPS Project? Assessing the Influence of Different Interest Groups', December.

EY. 2016. 'A New Mountain to Climb: Tax Reputation Risk, Growing Transparency Demands and the Importance of Data Readiness'. Tax risk and controversy survey series. EY.

Figueiredo, Rui J. P. De. 2002. 'Electoral Competition, Political Uncertainty, and Policy Insulation'. American Political Science Review $96 \quad$ (2): 321-33. https://doi.org/10.1017/S0003055402000199.

G8. 2013. '2013 Lough Erne G8 Leaders' Communiqué'. https://www.gov.uk/government/publications/2013-lough-erne-g8-leaderscommunique.

G20. 2012. 'G20 Leaders Declaration. Los Cabos, Mexico, 18-19 June 2012'.

Genschel, Philipp, and Thomas Rixen. 2015. 'Settling and Unsettling the Transnational Legal Order of International Taxation'. In Transnational Legal Orders, edited by Terence C. Halliday and Gregory Shaffer. New York: Cambridge University Press.

Haas, Peter M. 1992. 'Introduction: Epistemic Communities and International Policy Coordination'. International Organization 46 (1): 1-35.

KPMG. 2016. '2016 US CEO Survey'.

Lall, Ranjit. 2012. ‘From Failure to Failure: The Politics of International Banking Regulation'. Revien of International Political Economy 19 (4): 609-38. 
Lazega, Emmanuel. 1992. Micropolitics of Knowledge: Communication and Indirect Control in Workgroups. New York: Aldine de Gruyter.

Lesage, Dries, and Yusuf Kacar. 2013. 'Tax Justice through Country-by-Country Reporting: An Analysis of the Ideas' Political Journey'. In Tax Justice and the Political Economy of Global Capitalism, 1945 to the Present, edited by Jeremy Leaman and Attiya Waris, 1 edition, 262-82. New York: Berghahn Books.

Murphy, Richard. 2003. 'A Proposed International Accounting Standard: Reporting Turnover and Tax by Location'. Association for Accountancy and Business Affairs.

. 2012. 'Why Country-by-Country Reporting by Multinational Corporations Matters'. Tax $\begin{array}{lllll}\text { Research } & \text { UK } & \text { (blog). } & 20 & \text { February }\end{array}$ http://www.taxresearch.org.uk/Blog/2012/02/20/why-country-by-country-reportingby-multinational-corporations-matters/.

- 2013. 'Lough Erne and Country-by-Country Reporting'. TaxNotes International71 (3):249_ 53.

. 2014. 'Barclays: The Bank That Just Loves Luxembourg and Jersey, but Not the UK'. Tax $\begin{array}{lllll}\text { Research } & \text { UK } & \text { (blog). } & 30 & \text { June }\end{array}$ http://www.taxresearch.org.uk/Blog/2014/06/30/barclays-the-bank-that-just-lovesluxembourg-and-jersey/.

OECD. 2013. Action Plan on Base Erosion and Profit Shifting. OECD Publishing. http://www.oecdilibrary.org/taxation/action-plan-on-base-erosion-and-profit-shifting_9789264202719-en. . 2014a. 'Discussion Draft on Transfer Pricing Documentation and CbC Reporting'. Organisation for Economic Co-operation and Development.

—. 2014b. 'Public Comments Received: Discussion Draft on Transfer Pricing Documentation and CbC Reporting'. Organisation for Economic Co-operation and Development.

- 2014c. Guidance on Transfer Pricing Documentation and Country-by-Country Reporting. OECD/G20 Base Erosion and Profit Shifting Project. OECD Publishing. https://doi.org/10.1787/9789264219236-en.

Ougaard, Morten. 2011. 'Civil Society and Patterns of Accountability in the OECD'. In Building Global Democracy?: Civil Society and Accountable Global Governance, edited by Jan Aart Scholte, 1 edition. Cambridge, UK; New York: Cambridge University Press.

Oxfam. 2014. 'Business among Friends: Why Corporate Tax Dodgers Are Not yet Losing Sleep over Global Tax Reform'. 
2017. 'Opening the Vaults: The Use of Tax Havens by Europe's Biggest Banks'.

Picciotto, Sol. 2015. 'Indeterminacy, Complexity, Technocracy and the Reform of International Corporate Taxation'. Social \& Legal Studies 24 (2): 165-184.

PwC. 2016. 'Tax Strategy and Corporate Reputation: A Business Issue'. Global CEO Survey.

Quack, Sigrid. 2016. 'Organizing Counter-Expertise: Critical Professional Communities in Transnational Governance'. In The Organization of the Expert Society, edited by Andreas Werr and Staffan Furusten. Taylor \& Francis.

Rixen, Thomas. 2013. 'Why Reregulation after the Crisis Is Feeble: Shadow Banking, Offshore Financial Centers, and Jurisdictional Competition'. Regulation \& Governance 7 (4): 435-59.

Schreier, Margrit. 2012. Qualitative Content Analysis in Practice. London: SAGE Publications Ltd.

Seabrooke, Leonard, and Ole Jacob Sending. 2014. 'Open Systems of International Organization'. In $A G O R A V$. University of Warwick.

Seabrooke, Leonard, and Eleni Tsingou. 2014. 'Distinctions, Affiliations, and Professional Knowledge in Financial Reform Expert Groups'. Journal of European PublicPolicy 21 (3): 389_ 407. https://doi.org/10.1080/13501763.2014.882967.

Seabrooke, Leonard, and Duncan Wigan. 2015. 'How Activists Use Benchmarks: Reformist and Revolutionary Benchmarks for Global Economic Justice'. Review of International Studies 41 (05): 887-904.

. 2016. 'Powering Ideas through Expertise: Professionals in Global Tax Battles'. Journal of European Public Policy 23 (3): 357-74.

- 2017. 'The Governance of Global Wealth Chains'. Review of International PoliticalEconomy 24 (1): 1-29. https://doi.org/10.1080/09692290.2016.1268189.

Snow, David A., E. Burke Rochford, Steven K. Worden, and Robert D. Benford. 1986. 'Frame Alignment Processes, Micromobilization, and Movement Participation'. American Sociological Review 51 (4):464-81.

Tax Justice Network. 2013. 'Confronting Transfer Mispricing by the Use of Country by Country Reporting'.

Wilke, Claus O. 2018. Ggridges: Ridgeline Plots in 'Ggplot2' (version R package version 0.5.0.). https://CRAN.R-project.org/package=ggridges.

Young, Kevin L. 2012. 'Transnational Regulatory Capture? An Empirical Examination of the Transnational Lobbying of the Basel Committee on Banking Supervision'. Review of International PoliticalEconomy 19 (4): 663-88. 